\title{
TINJAUAN TENTANG KOLESTEROL DARAH PADA SOPIR BUS PARIWISATA DI KABUPATEN BADUNG
}

\author{
N L P. Gina Okta Verina ${ }^{1}$, Nyoman Mastra ${ }^{2}$, A.A. Md. Sucipta ${ }^{3}$ \\ Jurusan Analis Kesehatan Poltekkes Denpasar
}

\begin{abstract}
Background The lifestyle of consuming high fatty foods, smoking and drinking coffee frequently in the work place could be expected to cause high cholesterol that affects the health of the tourism bus driver.

Methods This research is a descriptive study. Tourism bus driver who works at Indah Putra Transport.

Result Of the 39 respondents obtained 18\% had normal cholesterol levels and $82 \%$ had high cholesterol levels. Based on the frequency of smoking every day, the highest frequency indicated by smoking more than 20 cigarettes per day by 25 respondents (64\%). The frequency of coffee consumption $<5$ cups per day, $41 \%$ had high cholesterol levels, consume coffee > 5 cups of coffee per day, 41\% have cholesterol levels high. Based on Physical activity habits 3-4 times a week indicated 5\% had high cholesterol levels and physical activity $<3$ times a week indicated 77\% had high cholesterol levels. 1-5 year working period earned as much as 8\% had high cholesterol levels, 6-10 year working period earned 3\% had normal cholesterol levels and 23\% had high cholesterol and the rest of the respondents were $51 \%$ in working period above of 11 years have high cholesterol levels.
\end{abstract}

Conclution It can be conceded that bad lifestyle of tourism bus drivers can affect the level of cholesterol.

Keywords : driver, cholesterol, lifestyle

\section{PENDAHULUAN}

Pengaruh globalisasi di segala bidang, perkembangan teknologi dan industri mengakibatkan perubahan pada perilaku dan gaya hidup masyarakat serta situasi lingkungannya, seperti perubahan pola konsumsi makanan, berkurangnya aktivitas fisik dan meningkatnya perilaku merokok. Menurut Tjandra, (2011) (dalam Situngkir, 2012) ${ }^{1}$. Perubahan tersebut telah memberi kontribusi terhadap semakin meningkatnya kasus-kasus penyakit tidak menular seperti; jantung, tumor, diabetes, hipertensi, gagal ginjal dan sebagainya. Menurut Riskesdas tahun $2007^{2}$ proporsi angka kematian penyakit tidak menular meningkat dari $41,7 \%$ pada tahun 1995 menjadi 59,5\% pada tahun 2007. Stroke merupakan penyebab utama kematian pada semua umur, jumlahnya mencapai $15,4 \%$. Angka kematian pada kelompok usia 45-54 tahun di daerah

\footnotetext{
1.,2.,3., Jurusan Analis Kesehatan Poltekkes Denpasar Korespondensi : N L P. Gina Okta Verina ${ }^{1}$, Jurusan Analis Kesehatan, Poltekes Denpasar, Jalan Sanitasi No. 1 Sidakarya, Denpasar-Bali 80224, Indonesia.

Telp. +62-361-710 527, Fax. +62-361-710 448

Email : meditoryjournal@gmail.com
}

Meditory | ISSN Online : 2549-1520, ISSN Cetak : 2338 - 1159, Vol. 5, No.1, Juni 2017 
perkotaan akibat stroke $15,9 \%$ yang merupakan penyebab utama kematian, sementara itu angka kematian pada kelompok usia 55-64 tahun di daerah perkotaan akibat stroke $26,8 \%$ sebagai penyebab utama kematian. Penyakit jantung dan stroke merupakan penyakit tidak menular yang menduduki peringkat pertama terbanyak penyebab kematian di dunia. Penyakit yang salah satunya disebabkan oleh penumpukan kolesterol pada pembuluh darah. (Kemenkes, 2012) ${ }^{3}$

Ditinjau dari sudut kimiawi, kolesterol diklasifikasikan ke dalam golongan lipid, yang berkomponen alkohol steroid yang sebagian besar berfungsi sebagai sumber kalori serta memberi nilai tambah terhadap citarasa makanan. (Sitepoe, 1992) ${ }^{4}$. Kolesterol merupakan salah satu komponen lemak yang ada dalam tubuh. Senyawa ini dikaitkan dengan pola makan tinggi lemak. Jika ditelaah lebih lanjut kolesterol merupakan zat yang diperlukan oleh tubuh yaitu untuk membantu hati menghasilkan empedu yang diperlukan untuk mencerna lemak, namun hal ini dikatakan baik jika kadar kolesterol normal. Selain kolesterol diproduksi oleh tubuh, kolesterol juga didapat dari makanan yaitu yang bersumber dari hewani contohnya cumi cumi, telur, produk susu, dan daging.
(Herlinawati, 2006) $)^{5}$. Adapun penelitian pendukung yang terkait dengan sopir bus pariwisata adalah Rizkawati, D (2012) ${ }^{6}$, dalam penelitiannya menyimpulkan bahwa terdapat hubungan yang bermakna antara kejadian hipertensi dengan riwayat hipertensi keluarga, indeks massa tubuh, lama bekerja sebagai sopir, kebiasaan makan buah dan sayur. Penelitian Russeng $(2009)^{7}$ menyimpulkan adanya hubungan yang bermakna antara kadar hemoglobin, hematokrit, IMT, dan asupan gizi memberikan kontribusi mengantuk terhadap sopir bus malam. Penelitian Musbyarini, dkk (2010) ${ }^{8}$ menyimpulkan terdapat hubungan yang signifikan antara tingkat kecukupan energi dengan status gizi sopir bus Sumber Alam di Kabupaten Purworejo

\section{METODE}

Penelitian ini adalah deskriptif yakni suatu penelitian yang menggambarkan atau memotret suatu masalah kesehatan serta yang terkait dengan kesehatan sekelompok penduduk atau orang yang tinggal dalam komunitas tertentu. Pendekatan yang digunakan yaitu pendekatan cross sectional yaitu suatu penelitian untuk mempelajari dinamika korelasi antara faktor-faktor risiko dengan efek, dengan cara pendekatan, observasi atau pengumpulan data sekaligus pada waktu 
yang sama. (Notoatmodjo, 2012) $)^{9}$. Populasi dari penelitian ini adalah sopir bus pariwisata yang bekerja di Indah Putra Transport yaitu sebanyak 39 orang.

1. Unit analisis dalam penelitian ini adalah sopir bus pariwisata dan responden dalam penelitian ini diambil dari karyawan sopir bus pariwisata di Indah Putra Transport yang memenuhi kriteria baik inklusi dan eksklusi. Kriteria inklusi dalam penelitian ini adalah : Sopir bus pariwisata yang bersedia menjadi sampel penelitian, Sopir bus pariwisata yang tidak memiliki penyakit keturunan, Sopir bus pariwisata harus puasa 8-12 jam sebelum pemeriksaan. Sedangkan kriteria eksklusi adalah Sopir bus pariwisata yang tidak bersedia menjadi sampel penelitian, Sopir bus pariwisata yang memiliki penyakit keturunan, Sopir bus pariwisata yang tidak melakukan puasa 8-12 jam sebelum pemeriksaan. Jumlah dan besar sampel. Menurut Arikunto (2006) ${ }^{10}$, apabila sampel penelitian kurang dari 100, lebih baik diambil semua sehingga penelitiannya merupakan penelitian populasi. Karena jumlah populasi dalam penelitian ini sebanyak 39 responden, maka besar sampel yang diteliti mencakup seluruh responden yang nantinya memenuhi kriteria baik inlusi maupun eksklusi. Teknik sampling dalam penelitian ini dilakukan secara sampling jenuh yaitu sampel diambil dari semua anggota populasi, hal ini dilakukan karena jumlah populasi sedikit. (Sugiyono, 2012) ${ }^{11}$. Analisis data yang dihasilkan tidak dianalisis secara statistik, namun akan dibahas dengan cara membandingkan hasil yang diperoleh dengan teori yang ada mengenai pemeriksaan kadar kolesterol darah.

\section{HASIL DAN PEMBAHASAN}

\section{HASIL}

\section{a. Kadar Kolesterol Sopir}

Hasil pemeriksaan kadar kolesterol pada 39 sopir bus diperoleh hasil keseluruhan sebanyak tujuh responden (18\%) yang mempunyai kadar kolesterol normal dan 32 responden (82\%) yang memiliki kadar kolesterol tinggi. Hasil selengkapnya dapat dilihat pada tabel1 berikut ini :

Tabel 1

Distribusi kadar kolesterol sopir bus pariwisata

\begin{tabular}{|c|c|c|c|}
\hline $\begin{array}{c}\text { Kadar } \\
\text { kolesterol }\end{array}$ & Jumlah & $\begin{array}{c}\text { Persentase } \\
(\%)\end{array}$ & $\begin{array}{c}\text { Nilai } \\
\text { rujukan }\end{array}$ \\
\hline Normal & 7 & 18 & $\begin{array}{c}(<200 \\
\mathrm{mg} / \mathrm{dL})\end{array}$ \\
\hline Tinggi & 32 & 82 & $\begin{array}{c}(>200 \\
\mathrm{mg} / \mathrm{dL})\end{array}$ \\
\hline Jumlah & 39 & 100 & \\
\hline
\end{tabular}


b. Kadar Kolesterol Pada Sopir Berdasarkan Frekuensi Merokok Setiap Hari

Dalam kebiasaan merokok ini dibagi menjadi empat kategori yaitu : kategori tidak merokok didapat hasil bahwa semua responden merokok. Pada kategori mengkonsumsi rokok kurang dari 10 batang/hari empat responden (10\%) memiliki kadar kolesterol normal. Dari 10 responden tiga responden $(8 \%)$ memiliki kadar kolesterol normal dan tujuh responden (18\%) memiliki kadar kolesterol tinggi pada kategori mengkonsumsi rokok 10-20 batang/hari. Pada kategori mengkonsumsi rokok lebih dari 20 batang/hari 25 responden (64\%) memiliki kadar kolesterol tinggi. Hasil selengkapnya dapat dilihat pada tabel 2 berikut ini :

Tabel 2

Kadar kolesterol pada sopir berdasarkan frekuensi merokok setiap hari

\begin{tabular}{|l|c|c|c|c|c|c|}
\hline \multirow{2}{*}{$\begin{array}{c}\text { Frekuensi } \\
\text { merokok/hari }\end{array}$} & \multicolumn{4}{|c|}{$\begin{array}{c}\text { Kadar kolesterol } \\
\text { (mg/dL) }\end{array}$} & \multicolumn{3}{c|}{ Total } \\
\cline { 2 - 6 } & Normal & \multicolumn{2}{|c|}{ Tinggi } & \multicolumn{2}{c|}{} \\
\cline { 2 - 6 } & $\Sigma$ & $\%$ & $\Sigma$ & $\%$ & $\Sigma$ & $\%$ \\
\hline $\begin{array}{l}\text { Tidak } \\
\text { merokok }\end{array}$ & 0 & 0 & 0 & 0 & 0 & 0 \\
\hline$<10$ batang & 4 & 10 & 0 & 0 & 4 & 10 \\
\hline $10-20$ batang & 3 & 8 & 7 & 18 & 10 & 26 \\
\hline
\end{tabular}

\begin{tabular}{|c|c|c|c|c|c|c|}
\hline$>20$ batang & 0 & 0 & 25 & 64 & 25 & 64 \\
\hline$\Sigma$ & 7 & 18 & 32 & 82 & 39 & 100 \\
\hline
\end{tabular}

Keterangan $\Sigma$ : jumlah

\section{c. Kadar Kolesterol Pada Sopir Berdasarkan Frekuensi \\ Mengkonsumsi Kopi Setiap Hari}

Hasil pemeriksaan kolesterol berdasarkan frekuensi mengkonsumsi kopi setiap hari pada 39 sopir bus pariwisata adalah sebagai berikut mengkonsumsi kopi kurang dari 5 gelas/hari dari 21 responden terdapat lima responden (13\%) memiliki kadar kolesterol normal dan 16 responden (41\%) memiliki kadar kolesterol tinggi. Berdasarkan mengkonsumsi kopi lebih dari 5 gelas/hari dari 18 responden dua responden $(5 \%)$ memiliki kadar kolesterol normal dan 16 responden $(41 \%)$ memiliki kadar kolesterol tinggi. Hasil selengkapnya dapat dilihat pada tabel 3 berikut ini :

Tabel 3

Kadar kolesterol pada sopir berdasarkan frekuensi mengkonsumsi kopi setiap hari

\begin{tabular}{|c|c|c|c|c|c|c|}
\hline \multirow{2}{*}{$\begin{array}{c}\text { Frekuensi } \\
\text { mengkons } \\
\text { umsi kopi } \\
\text { setiap hari }\end{array}$} & \multicolumn{4}{|c|}{$\begin{array}{c}\text { Kadar kolesterol } \\
(\mathrm{mg} / \mathrm{dL})\end{array}$} & \multicolumn{2}{c|}{ Total } \\
\cline { 2 - 6 } & Normal & \multicolumn{2}{|c|}{ Tinggi } & \multicolumn{2}{|c|}{} \\
\cline { 2 - 7 } & $\Sigma$ & $\%$ & $\Sigma$ & $\%$ & $\Sigma$ & $\%$ \\
\hline$<5$ gelas & 5 & 13 & 16 & 41 & 21 & 54 \\
\hline$>5$ gelas & 2 & 5 & 16 & 41 & 18 & 46 \\
\hline$\Sigma$ & 7 & 18 & 32 & 82 & 39 & 100 \\
\hline
\end{tabular}

Meditory | ISSN Online : 2549-1520, ISSN Cetak : 2338 - 1159, Vol. 5, No.1, Juni 2017 
Keterangan $\Sigma:$ Jumlah

\section{d. Kadar Kolesterol Pada Sopir} Berdasarkan Kebiasaan Melakukan Olah Raga

Berdasarkan kebiasaan melakukan aktivitas fisik seperti olahraga pada 39 sopir bus pariwisata, aktivitas fisik disini dikategorikan menjadi dua yaitu pada kebiasaan olahraga 3-4 kali dalam seminggu dari empat responden terdapat dua responden (5\%) memiliki kadar kolesterol normal dan dua responden (5\%) memiliki kadar kolesterol tinggi. Pada kebiasaan olahraga kurang dari 3 kali dalam seminggu dari 35 responden terdapat lima responden (13\%) memiliki kadar kolesterol normal dan 30 responden (77\%) memiliki kadar kolesterol tinggi. Hasil dapat dilihat pada tabel 4 berikut ini

Tabel 4

Kadar kolesterol berdasarkan kebiasaan melakukan aktivitas fisik

\begin{tabular}{|c|c|c|c|c|c|c|}
\hline \multirow{2}{*}{$\begin{array}{l}\text { Frekuensi } \\
\text { kebiasaan } \\
\text { melakukan }\end{array}$} & \multicolumn{4}{|c|}{$\begin{array}{l}\text { Kadar kolesterol } \\
(\mathrm{mg} / \mathrm{dL})\end{array}$} & \multicolumn{2}{|c|}{ Total } \\
\hline & \multicolumn{2}{|c|}{ Normal } & \multicolumn{2}{|c|}{ Tinggi } & & \\
\hline $\begin{array}{c}\text { ( Dalam } \\
\text { seminggu) }\end{array}$ & $\Sigma$ & $\%$ & $\Sigma$ & $\%$ & $\Sigma$ & $\%$ \\
\hline
\end{tabular}

\begin{tabular}{|c|c|c|c|c|c|c|}
\hline $3-4$ kali & 2 & 5 & 2 & 5 & 4 & 10 \\
\hline$<3$ kali & 5 & 13 & 30 & 77 & 35 & 90 \\
\hline$\Sigma$ & 7 & 18 & 32 & 82 & 39 & 100 \\
\hline
\end{tabular}

Keterangan $\Sigma$ : jumlah

\section{e. Kadar kolesterol berdasarkan masa}

\section{kerja sebagai sopir bus pariwisata}

Berdasarkan Masa kerja sebagai sopir didapatkan hasil pada 39 responden adalah pada kategori 1-5 tahun dari sembilan responden enam responden (15\%) memiliki kadar kolesterol normal, dan tiga responden (8\%) memiliki kadar kolesterol tinggi. Pada kategori 6-10 tahun dari 10 responden satu responden (3\%) memiliki kadar kolesterol normal dan sembilan responden (23\%) memiliki kadar kolesterol tinggi. Pada kategori 11-20 tahun tiga $(8 \%)$ responden memiliki kadar kolesterol tinggi. Pada kategori 16-20 tahun tiga responden (8\%) memiliki kadar kolesterol tinggi. Pada kategori 21-25 tahun enam responden (15\%) memiliki kadar kolesterol tinggi. Kategori 26-30 tahun delapan responden (20\%) memiliki

Meditory | ISSN Online : 2549-1520, ISSN Cetak : 2338 - 1159, Vol. 5, No.1, Juni 2017 
kadar kolesterol tinggi. Hasil dapat dilihat

pada tabel 5 berikut ini :

Tabel 5

Kadar kolesterol berdasarkan masa kerja sebagai sopir bus pariwisata

\begin{tabular}{|c|c|c|c|c|c|c|}
\hline \multirow{2}{*}{ Masa Kerja } & \multicolumn{4}{|c|}{$\begin{array}{c}\text { Kadar kolesterol } \\
\text { (mg/dL) }\end{array}$} & \multicolumn{2}{c|}{ Total } \\
\cline { 2 - 6 } & \multicolumn{2}{|c|}{ Normal } & \multicolumn{2}{c|}{ Tinggi } & \multicolumn{2}{c|}{} \\
\cline { 2 - 6 }$\Sigma$ & $\Sigma$ & $\Sigma$ & $\%$ & $\Sigma$ & $\%$ \\
\hline $1-5$ tahun & 6 & 15 & 3 & 8 & 9 & 23 \\
\hline $6-10$ tahun & 1 & 3 & 9 & 23 & 10 & 26 \\
\hline $11-15$ tahun & 0 & 0 & 3 & 8 & 3 & 8 \\
\hline $16-20$ tahun & 0 & 0 & 3 & 8 & 3 & 8 \\
\hline $21-25$ tahun & 0 & 0 & 6 & 15 & 6 & 15 \\
\hline $26-30$ tahun & 0 & 0 & 8 & 20 & 8 & 20 \\
\hline$\Sigma$ & 7 & 18 & 32 & 82 & 39 & 100 \\
\hline
\end{tabular}

Keterangan $\Sigma:$ jumlah

\section{PEMBAHASAN}

\section{a. Kolesterol Darah Responden}

Hasil pemeriksaan kadar kolesterol yang diperiksa dari 39 responden sopir bus pariwisata tujuh responden (18\%) yang memiliki kadar kolesterol normal dan 32 responden (82\%) memiliki kadar kolesterol tinggi, hal ini menunjukkan sebagian besar sopir bus pariwisata memiliki kadar kolesterol tinggi. Secara keseluruhan kebiasaan-kebiasaan dari responden mendukung kadar kolesterol tinggi. Seperti kebiasaan merokok, minum kopi, serta jarang berolahraga. Nilawati, dkk (2008) ${ }^{12}$ mengatakan kebiasaan seperti merokok dan minum kopi juga dapat berkontribusi besar dalam naiknya kadar kolesterol total. Cahyono $(2008)^{13}$ juga sependapat mengenai aktivitas fisik yang kurang dapat berdampak buruk terhadap kesehatan, yang menyatakan "aktivitas fisik dapat menurunkan kadar lemak darah seperti trigliserida dan kolesterol LDL (Low Density Lipoprotein), serta dapat meningkatkan lemak baik yaitu kolesterol HDL (High Density Lipoprotein)".

\section{b. Kadar kolesterol pada sopir bus pariwisata berdasarkan kebiasaan merokok}

Dari hasil yang didapat bahwa tidak ada sopir yang tidak merokok, hal ini dikarenakan merokok dapat menghilangkan rasa kantuk dan memberi rasa rileks setiap menghisapnya. Dari empat responden (10\%) memiliki kadar kolesterol normal pada kategori mengkonsumsi rokok kurang dari 10 batang/hari. Dalam kategori mengkonsumsi rokok 10-20 batang/hari dari 10 responden (26\%) tiga responden (8\%) memiliki kadar kolesterol normal sedangkan tujuh responden (18\%) memiliki kadar kolesterol tinggi. Pada kategori mengkonsumsi rokok lebih dari 20 batang/hari dari 25 responden (64\%) 
semua memiliki kadar kolesterol tinggi. Hasil ini menunjukkan kadar kolesterol dipengaruhi oleh konsumsi rokok setiap hari. Hasil ini didukung oleh penelitian Mamat dan Sudikno (2010) ${ }^{14}$ yang menyatakan bahwa penurunan High Density Lipoprotein (HDL) tidak hanya dipengaruhi oleh berapa lama seseorang menghisap rokok tetapi dipengaruhi juga jumlah batang rokok yang dihisap setiap hari. Frekuensi merokok merupakan faktor yang paling berpengaruh terhadap kolesterol HDL.

\section{c. Kadar kolesterol pada sopir bus pariwisata berdasarkan kebiasaan mengkonsumsi kopi \\ Dari hasil penelitian}

mengkonsumsi kopi dibagi menjadi dua kategori, dimana pada kategori mengkonsumsi kurang dari 5 gelas/hari dari 21 responden (54\%) lima responden (13\%) memiliki kadar kolesterol normal dan 16 responden (41\%) memiliki kadar kolesterol tinggi. Pada kategori mengkonsumsi kopi lebih dari lima gelas kopi setiap hari dari 18 responden (46\%) dua responden (5\%) memiliki kadar kolesterol normal dan 16 responden (41\%) memiliki kadar kolesterol tinggi. Dari data yang diperoleh, kadar kolesterol berdasarkan kebiasaan minum kopi lebih dari lima gelas setiap hari menunjukkan perbandingan yang lebih tinggi dibandingkan konsumsi kurang dari lima gelas setiap hari. Namun dilihat dari data keseluruhan sebagian besar responden memiliki kadar kolesterol tinggi. Hasil yang diperoleh sesuai dengan teori yang menyatakan salah satu penyebab dari kadar kolesterol tinggi adalah kebiasaan minum kopi yang berlebihan, karena kandungan cafestol dari kopi dapat meningkatkan risiko naiknya kolesterol. Senyawa ini keluar ketika air panas dituangkan langsung pada kopi bubuk atau kopi bubuk direbus dalam air mendidih beberapa kali. Secangkir kopi tubruk mengandung sekitar empat milligram cafestol, yang dapat meningkatkan kadar kolesterol LDL $1 \%$ dalam darah. (Deherba, 2015) ${ }^{15}$ Mengkonsumsi lebih dari lima cangkir kopi sehari dapat meningkatkan risiko infark sampai $70 \%$. Pada jangka lama mengkonsumsi terlalu banyak kopi juga mengakibatkan meningkatnya LDL. (Tjay dan Kirana, 2007) $)^{16}$

\section{d. Kadar kolesterol pada sopir bus pariwisata berdasarkan kebiasaan melakukan aktivitas fisik}

Menurut Cahyono (2008) ${ }^{13}$ aktivitas fisik seperti olahraga harus dilakukan rutin setiap minggu untuk menunjang kesehatan, tetapi karena waktu yang sedikit membuat 
masyarakat menjadi tidak sempat untuk berolahraga secara rutin. Dari hasil penelitian kebiasaan melakukan aktivitas fisik terdapat 39 responden, dari empat responden $(10 \%)$ dua responden $(5 \%)$ memiliki kadar kolesterol normal dan dua responden (5\%) memiliki kadar kolesterol tinggi hasil ini merupakan kebiasaan melakukan aktivitas fisik yang dilakukan tiga sampai empat kali dalam seminggu. Pada responden yang melakukan aktivitas fisik kurang dari tiga kali dalam seminggu terdapat 35 responden $(90 \%)$ lima responden (13\%) memiliki kadar kolesterol normal dan 30 responden $(77 \%)$ memiliki kadar kolesterol tinggi. Data tersebut sesuai dengan penelitian dari Hengkengbala dkk $(2013)^{17}$ yang menyatakan bahwa latihan fisik aerobik dapat mempengaruhi kadar HDL dalam darah. Ini dapat dilihat pada perubahan kadar HDL yang terjadi sebelum dan sesudah melakukan latihan fisik aerobik mengalami peningkatan. Nilawati dkk (2008 dalam Hartini dan Mulyanti, 2009) ${ }^{18}$ menyatakan berolahraga secara teratur juga akan meningkatkan aktivitas berbagai enzim yang bertanggung jawab terhadap oksidasi lemak sehingga banyak lemak yang digunakan sebagai sumber energi.

\section{e. Kadar kolesterol pada sopir bus pariwisata berdasarkan lamanya bekerja}

Berdasarkan hasil penelitian ditemukan sembilan responden (23\%) yang bekerja selama 1-5 tahun, sebanyak enam responden (15\%) memiliki kadar kolesterol normal dan tiga responden $(8 \%)$ memiliki kadar kolesterol tinggi. Dari 10 responden (26\%) yang bekerja 6-10 tahun, sebanyak satu responden (3\%) memiliki kadar kolesterol normal dan sembilan responden (23\%) memiliki kadar kolesterol tinggi. Dari tiga responden yang bekerja selama 11-15 tahun, sebanyak tiga responden $(8 \%)$ memiliki kadar kolesterol tinggi. Dari tiga responden yang bekerja selama 16-20 tahun, sebanyak tiga responden $(8 \%)$ memiliki kadar kolesterol tinggi. Dari enam responden yang bekerja selama 21-25 tahun, sebanyak enam responden (15\%) memiliki kadar kolesterol tinggi. Dari delapan responden yang bekerja selama 26-30 tahun, sebanyak delapan responden (20\%) memiliki kadar kolesterol tinggi. Dari data tersebut dapat dilihat masa kerja sebagai sopir bus pariwisata dapat berpengaruh terhadap kadar kolesterol. Hal ini juga didukung dari kebiasaan yang lain seperti merokok dan minum kopi. Menurut Stanley dan Beare (2007) dalam Hartini 
dan Mulyanti, 2009) ${ }^{18}$ menyatakan bahwa kadar kolesterol akan mengalami peningkatan secara bertahap seiring bertambahnya usia karena organ di dalam tubuh mengalami penurunan, baik penurunan struktur maupun fungsi.

\section{SIMPULAN DAN SARAN}

\section{Simpulan}

Berdasarkan hasil penelitian ini maka dapat disimpulkan:

1. Dari 39 sopir bus pariwisata, 32 orang memiliki kadar Kolesterol tinggi

2. Mengkonsumsi rokok semua kategori sama-sama memiliki kadar Kolesterol tinggi, dengan rerata 16, mengkonsumsi kopi semua kategori memiliki kadar Kolesterol tinggi, dengan rerata 16 , melakukan aktivitas fisik semua kategori ada yang memiliki kadar Kolesterol tinggi dengan rerata 16., berdasarkan masa kerja memiliki kadar kolesterol tinggi dengan rerata 16 juga

3. Pada semua kategori masa kerja ada dengan kadar Kolesterol tinggi

\section{Saran-Saran}

Sopir bus pariwisata disarankan untuk mengurangi merokok dan mengkonsumsi kopi serta lebih sering beraktivitas olah raga sehingga kadar Kolesterol tetap normal, disarankan untuk melakukan pemeriksaan Kolesterol secara rutin setiap bulan untuk mengetahui perkembangan kesehatan dan menerapkan pola hidup yang baik

\section{DAFTAR PUSTAKA}

1. Situngkir, L.,N.Pengetahuan dan Sikap Terhadap Gaya Hidup Sehat Pada Mahasiswa Fakultas Kesehatan Masyarakat Universitas Sumatera Utara tahun 2012, Medan: Universitas Sumatera Utara, 2012

2. Riset Kesehatan Dasar, Badan Penelitian dan Pengembangan Kesehatan, Jakarta:Departemen Kesehatan, Republik Indonesia, 2007

3. Kemenkes, Penyakit Tidak Menular, Jakarta: Kementerian Kesehatan RI, 2012

4. Sitepoe, M., Kolesterol Fobia, Cetakan Pertama, Jakarta: Gramedia Pustaka Utama, 1992

5. Herlinawati, Y. Terapi Jus Untuk Kolesterol, Cetakan I, Jakarta: Puspa Swara, 2006

6. Rizkawati, D. Indeks Masssa Tubuh, Lama Bekerja, Kebiasaan Makan, dan Gaya Hidup Hubungannya dengan Hipertensi pada Pengemudi Bus Trans 
Jakarta tahun 2012, Jakarta:

Universitas Indonesia, 2012

7. Russeng, S., S., Status Gizi dan Kelelahan Kerja, (Kajian Pada Pengemudi Bus Malam di Sulawesi Selatan dan Barat), Makasar: Universitas Hasanuddin, 2009

8. Musbyarini, K., Faisal, A., dan Cesilia, M., D. Gaya Hidup dan Status Kesehatan Sopir Bus Sumber Alam di Kabupaten Purworejo, Jawa Tengah, Bogor: Institut Pertanian Bogor, 2010

9. Notoatmodjo, S. Metode Penelitian Kesehatan, Edisi Revisi, Cetakan Kedua, Jakarta: Rineka Cipta, 2012

10. Arikunto, S. Prosedur Penelitian Suatu Pendekatan Praktik Edisi Revisi VI, Jakarta: PT. Rineka Cipta, 2006

11. Sugiyono, Metode Penelitian Kuantitatif Kualitatif dan $R \& D$, Cetakan ke - 15, Bandung: CV. Alfabeta, 2012

12. Nilawati, S.,dkk., Care Your Self Kolesterol, Cetakan I, Jakarta: Penebar Plus, 2008

13. Cahyono, J.,B.,S.,B., Gaya Hidup dan Penyakit Modern, Cetakan I, Yogyakarta: Kanisius, 2008

14. Mamat dan Sudikno. Faktor-Faktor Yang Berhubungan Dengan Kadar Kolesterol HDL (Analisis Data Of The Indonesian Family Life Survey
2007/2008), Bogor: Poltekkes Depkes Bandung, 2010

15. Deherba, 2015, Kopi, Dapatkah Meningkatkan Kadar Kolesterol, (online), available

http://www.deherba.com/kopidapatkah-meningkatkan-kadarkolesterol.html, (1 Juli 2015)

16. Tjay, T.,H., dan Kirana, R., Obat-Obat Penting Khasiat, Penggunaan dan Efek-Efek Samping, Edisi ke-IV, Cetakan Pertama, Jakarta: PT Elex Media Komputindo, 2007

17. Hengkengbala, dkk Pengaruh Latihan Fisik Aerobik Terhadap Kolesterol High Density Lipoprotein (Hdl) Pria Dengan Berat Badan Lebih (Overweight), Manado : Fakultas Kedokteran Universitas Sam Ratulangi, 2013

18. Hartini dan Mulyanti, Efektivitas Senam Lansia Terhadap Penurunan Kadar Kolesterol Darah Pada Lansia Merokok Di Dusun Pirak Mertosutan Sidoluhur Godean Sleman Yogyakarta Tahun 2009, Yogyakarta : STIKES Kusuma Husada Surakarta, 2009

Meditory | ISSN Online : 2549-1520, ISSN Cetak : 2338 - 1159, Vol. 5, No.1, Juni 2017 60 HIm. 51-60, http://ejournal.poltekkes-denpasar.ac.id 